\title{
The effect of glyphosate-based herbicide on aquatic organisms - a case study
}

\author{
Piotr Rzymski ${ }^{1}$, Piotr Klimaszyk², Tomasz Kubacki ${ }^{1}$, Barbara Poniedziałek ${ }^{1}$ \\ ${ }^{1}$ Department of Biology and Environmental Protection, Poznan University of Medical Sciences, Rokietnicka 8, 60-806 Poznań, Poland, \\ e-mail: rzymskipiotr@ump.edu.pl (corresponding author) \\ ${ }^{2}$ Department of Water Protection, Adam Mickiewicz University, Umultowska 89, 61-614 Poznań, Poland
}

\begin{abstract}
The non-selective, post-emergence herbicides based on glyphosate [N-(phosphonomethyl) glycine] are one of the most widely used pesticides in agriculture, urban areas and forestry. Although there has been documentation on the physical, chemical and toxicological properties of glyphosate, the aquatic toxicity of such formulations still requires assessment and evaluation. In the present study, we describe deliberate use of glyphosate-based herbicide in a bathing area of Lake Lednica (Wielkopolska, Poland) by unknown perpetrators in April, 2011. Glyphosate was detected using gas chromatography mass spectrometry (GC-MS) in the water samples collected from the bathing area at a mean concentration of $0.09 \mathrm{mg} \mathrm{dm}^{-3}$. Aboveground parts of emerged macrophytes (Phragmites australis and Typha latifolia) covering the investigated area were completely withered. Studies of benthic macroinvertebrates revealed no significant differences in taxa number between event (13 taxa) and control (14 taxa) sites although differences in abundance of particular taxa were observed. Significantly lower numbers of Chironomidae (by 41\%), Oligochaeta (by 43\%), Vivipariae (by 75\%), Hirudinae (by 75\%), Asellus aquaticus (by 77\%), Gammarus pulex (by 38\%) and Dreissena polymorpha (by $42 \%$ ) were found at the glyphosate-treated site. Furthermore, compared to the control, chironomids (Chironomidae) exposed to glyphosate were represented by specimens smaller in length while A. aquaticus only showed large adults. The ranges of glyphosate concentration in the tissues of sampled macroinvertebrates and Phragmites australis organs were $7.3-10.2 \mu \mathrm{g} \mathrm{kg}^{-1}$ and $16.2-24.7 \mu \mathrm{gg}^{-1}$, respectively. Our study indicates that glyphosate-based herbicides may have adverse effects on aquatic organisms including macroinvertebrates, thus their use in (or nearby) surface waters should be subject to strict limitation.
\end{abstract}

Key words: glyphosate, herbicides, macroinvertebrates, emergent macrophytes, Lake Lednica

\section{Introduction}

Glyphosate [(N-phosphonomethyl-glycine; CAS number: 1071-83-6)] is the primary non-selective active ingredient of various herbicides applied for the control of weeds in agricultural, urban and household settings. Registered in 1971 in the United States as a broad-spectrum, post-emergence herbicide, it is legalized in over 130 countries including Poland and usually sold under the commercial label of Roundup ${ }^{\mathrm{TM}}$ (Pieniążek et al. 2003). Once applied on aboveground parts of plants, it is rapidly translocated from the leaves to other organs - growing tips of stems and roots, rhizomes and tubers. When applied to soil, glyphosate reveals low activity because of the strong binding to soil organic matter, which in turn makes this compound biologically unavailable (Solomon and Thompson 2003).
The mechanism of action of glyphosate is mediated through the inhibition of the 5-enolpyruvyl shikimate3-P synthetase, an essential enzyme in the pathway to the synthesis of the aromatic amino acids in plants and some microorganisms (Steinrücken and Amrhein 1980). Biochemical symptoms of toxicity in plants include decreases in concentration of the aromatic amino acids, tryptophan, phenylalanine, and tyrosine, as well as decreased synthesis of protein, indole acetic acid and chlorophyll. The death of the plant is first seen as a cessation of growth, followed by chlorosis and then massive necrosis of plant tissues (Solomon and Thompson 2003).

Apart from their use in terrestrial environments, glyphosate-based formulas are also, however rarely, applied in order to control aquatic weeds, particularly invasive species e.g. common reed (Phragmites australis) 
in the eastern United States. Glyphosate still remains the only herbicide product certified by the US Environmental Protection Agency (USEPA) for use in aquatic environments. Chemically, glyphosate closely resembles naturally occurring substances and does not possess chemical groups that would confer great reactivity, atmospheric mobility, or biological persistence. Its chemical and physical properties indicate that it should not bioaccumulate, nor biomagnify through the food chain to any considerable extent (USEPA 1993; WHO 1994; Giesy et al. 2000).

Due to their efficiency, the use of glyphosatebased herbicides is steadily growing. Widespread application of glyphosate formulations requires special attention to their possible transport from land to surface waters. Glyphosate demonstrates high solubility in water although it is readily ionized and, as the anion, usually strongly adsorbed to sediments of $\mathrm{pH}>3.5$. It thus has almost no mobility in water and is rapidly removed to sediments and suspended particulate matter (Solomon and Thompson 2003). This, however, does not exclude its potential toxicity to living organisms particularly related to the bottom layers of lakes and rivers and those feeding upon the particulate matter.

In April, 2011 we observed rapid, unexpected and widespread withering of the emerged plants overgrowing the bathing area of Lake Lednica (Western Poland). We suspected illegal use of herbicide by unknown perpetrators. In the present study, we describe the confirmation of glyphosate use by its determination in water and biological samples. We also report the observed effects of this herbicide on emerged plants as well as the benthic macroinvertebrate community which inhabited associated sediments. To our knowledge this is the only description of the deliberate and illegal use of the glyphosate-based formulation in aquatic environments in Poland.

\section{Study site}

Lake Lednica is situated within a protected area of Lednica Landscape Park in the southern part of the Gniezno Lakeland about $35 \mathrm{~km}$ east of the City of Poznan in west-central Poland (Fig. 1). The genesis of the lake is related to the last glaciation in Poland.

Lake Lednica covers an area of 339.1 ha and fills the southern part of a tunnel valley which extends between Janowiec and Lednogóra. It is an elongated water body with a total length of $7.3 \mathrm{~km}$, maximum width of $825 \mathrm{~m}$, and maximum depth of $15.1 \mathrm{~m}$. Several small streams flow into the lake. The catchment area covers over $384 \mathrm{~km}^{2}$ dominated by cultivated lands. The lake has four islets and a varied shoreline $22 \mathrm{~km}$ long.

\section{Material and methods}

\section{Sampling}

The sampling site was situated at the bathing area of Lake Lednica - near the village of Lednogóra (Fig. 1). Samples of emerged plants - Phragmites australis (Cav.) Trin. ex Steud. - were collected manually from a $0.5 \mathrm{~m}$ $\times 0.5 \mathrm{~m}$ plot. Leaves, stems and roots were stored separately in a freezer at $-20^{\circ} \mathrm{C}$. Water was collected from a depth of $0.5 \mathrm{~m}$ in a plastic bottle. In the laboratory water was filtered through a GF/C filter. Benthic macroinvertebrates were collected together with sediments using a littoral core sampler. For each station 17 subsamples were taken. At both stations subsamples were collected from similar habitats - within submerged macrophytes. The collected material was sieved through a $0.25 \mathrm{~mm}$ mesh. After taxonomical identification, individuals were frozen at $-20^{\circ} \mathrm{C}$.

As control we collected samples from a site located $200 \mathrm{~m}$ from the event site (Fig. 1). No visible signs of plants withering or other potential toxic effects of herbicide were observed.

\section{Glyphosate determination}

Glyphosate concentration in water and biota was determined using a gas chromatography - mass spectrometry (GC/MS) system (Varian 3400, Australia). Capillary column Agilent Hp-5ms (0.32 mm ID × $30 \mathrm{~m}$ length $\times 0.25 \mu \mathrm{m}$ thickness film) was applied. The chromatographic conditions were as follows: manifold temperature $-220^{\circ} \mathrm{C}$; transfer line temperature $-200^{\circ} \mathrm{C}$; injector temperature $-150^{\circ} \mathrm{C}$; oven temperature programme $-1.0 \mathrm{~min}$ at $100^{\circ} \mathrm{C}, 10^{\circ} \mathrm{C} \mathrm{min}{ }^{-1}$ to $130^{\circ} \mathrm{C}, 1^{\circ} \mathrm{C}$ $\mathrm{min}^{-1}$ to $133^{\circ} \mathrm{C}$, hold for $8.0 \mathrm{~min}, 17^{\circ} \mathrm{C} \mathrm{min}{ }^{-1}$ to $150^{\circ} \mathrm{C}$, hold for $2.0 \mathrm{~min}$. The total run time was $18 \mathrm{~min}$. The injection volume was $2 \mathrm{~mm}^{3}$ with split 1:80. Helium maintained at a constant flow rate of $0.5 \mathrm{~cm}^{3} \mathrm{~min}^{-1}$ was used as the carrier gas. The approximate retention time of the glyphosate-derivatization was $16.2 \mathrm{~min}$. Standard glyphosate (IPO, Poland) was dissolved in distilled water $\left(250 \mathrm{~cm}^{3}\right)$. Calibration solutions $(0.1,0.5,2.5,5.0$, 10.0 and $20 \mu \mathrm{g} \mathrm{cm}^{-3}$ ) were made by dilution.

Homogenized macroinvertebrates and plant samples (2-3 g) were shaken separately for $30 \mathrm{~min}$ utes with $25 \mathrm{~cm}^{3}$ of $2 \mathrm{M} \mathrm{NH}_{4} \mathrm{OH}$ and centrifuged at 


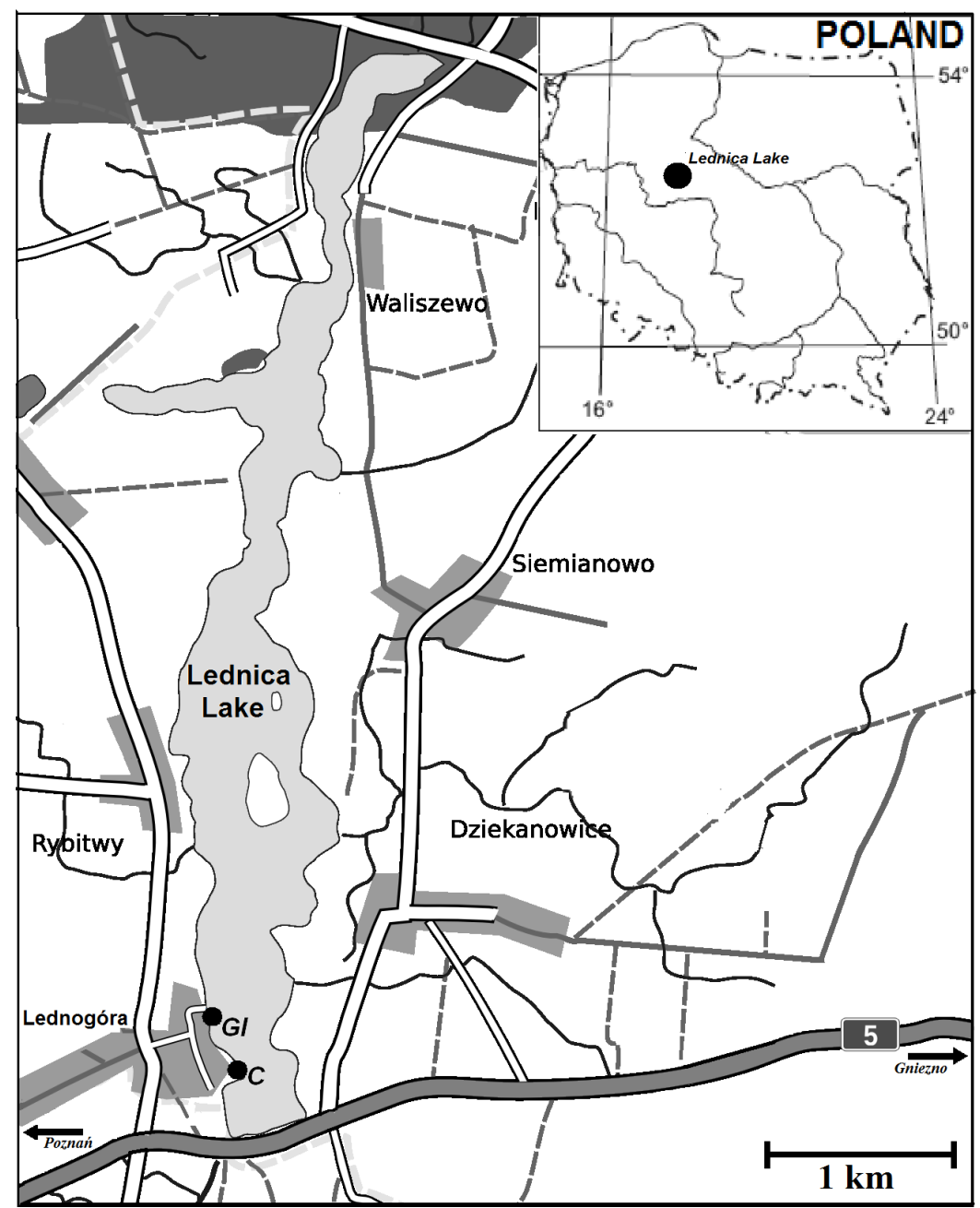

Fig. 1. The study sites and location of Lake Lednica. Gl - glyphosate treated site, C - control site

$5000 \mathrm{rpm}$ for another $30 \mathrm{~min}$. The supernatant fractions were evaporated to dryness under vacuum. Water samples $\left(25-30 \mathrm{~cm}^{3}\right)$ were evaporated. The residues were dissolved in $6 \mathrm{~cm}^{3}$ of water-methanol-hydrochloric acid (40:10:1) with the addition of $40 \mathrm{~cm}^{3}$ of $85 \%$ phosphoric acid. Samples were then incubated at $20^{\circ} \mathrm{C}$ for $2 \mathrm{~h}$ and centrifuged at $5000 \mathrm{rpm}$ for another 30 $\mathrm{min}$. Supernatants were evaporated in flasks equipped with a reflux condenser protected by a drying tube. After chilling the flasks $\left(4^{\circ} \mathrm{C}\right)$ and adding the derivatization reagents $-2 \mathrm{~cm}^{3}$ of trifluoroacetic anhydride (TFAA) and $1 \mathrm{~cm}^{3}$ of 2,2-trifluoroethanol (TFE) the mixture was held for $1 \mathrm{~h}$ in an oil bath at $100^{\circ} \mathrm{C}$. The excess of derivatization reagents was removed by evaporation. The flask was rinsed with distilled water and methylene chloride and solvents were transferred to a separator funnel. After shaking for $2 \mathrm{~min}$, the organic layer was collected. The extraction process was performed in triplicate. The combined organic layers were dried over anhydrous magnesium sulphate, and evaporated to remove the solvent. The residue was dissolved in $1 \mathrm{~cm}^{3}$ of ethyl acetate, and filtered by $0.20 \mu \mathrm{m}$ PTFE syringe filter and then injected into GC.

\section{Results and discussion}

Glyphosate was detected in water collected from the bathing area of Lake Lednickie. Mean determined concentration was $90 \pm 10.0 \mu \mathrm{g} \mathrm{dm}^{-3}$. No glyphosate was found in water at the control station. As demonstrated in other studies, glyphosate concentration in water is highly situation-dependent and can vary largely. For example Schmidt and Boas (2006) found relatively low levels ranging up to $5 \mu \mathrm{g} \mathrm{dm}^{-3}$ in the River Havel (Germany) located in the upstream and downstream of the urban area. On the other hand, Peruzzo et al. (2008) 
found that glyphosate concentration in streams near cultivated fields in Argentina can be as high as $400 \mu \mathrm{g}$ $\mathrm{dm}^{-3}$ after agricultural glyphosate-based application and over $600 \mu \mathrm{g} \mathrm{dm}^{-3}$ after heavy rainfall. Glyphosate in aquatic environments is usually quickly removed to particulate matters and deposited in sediments. Its degradation depends on the physicochemical conditions of water and activity of microorganisms. Tests performed by the U.S. Environmental Protection Agency revealed that the half-life of glyphosate in natural water ranged from 35 to 63 days (USEPA 1986). Goldsborough and Beck (1989) observed even faster dissipation of glyphosate in small forest ponds with first order half-lives ranging from only 1.5 to 3.5 days. The first product of glyphosate degradation is AMPA (aminomethylphosphonic acid) (Rueppel et al. 1977). This metabolite is also frequently found in surface water with agricultural catchment areas (Coupe et al. 2012). AMPA is believed to be less toxic than glyphosate although its degradation in the environment is generally slower (Bonnet et al. 2007; Pérez et al. 2011).

The concentration found in our study indicates that glyphosate-based herbicide was the direct cause of the withering of the plants and that it could potentially have other toxic effects on aquatic organisms inhabiting the littoral zone. It was already found in numerous investigations that glyphosate induces adverse effects in fish and amphibians (Modesto and Martinez 2010; Jones et al. 2010; Glusczak et al. 2011; Edge et al. 2013; Sandrini et al. 2013; Vera-Candioti et al. 2013). It was, however, demonstrated that glyphosate in environment-relevant concentrations does not reveal significant effects on aquatic crustaceans (Linz et al. 1999) but can temporarily affect zooplankton diversity by eliminating cladocerans but not copepods - the latter increased in abundance (Relyea 2005). Glyphosate can be largely deposited in the sediments, thus it was expected that its effects could manifest in macroinvertebrates inhabiting the benthos of the bathing area in Lake Lednickie. We did not find significant differences in taxa number between the bathing area (12 taxa) and the control site (13 taxa) although there was a difference in abundance of specimens and taxonomic composition. The density of the benthic macroinvertebrates found at the bathing area was over $40 \%$ lower than at the control site (Table 1). We found significantly lower abundance of midges from the family Chironomidae (41\%), Oligochaeta (43\%), Vivipariae snails (75\%), leeches (75\%), freshwater crustaceans: Asellus aquaticus (77\%), Gammarus pulex (38\%) and zebra mussel Dreissena poly- morpha (42\%) (Table 1). Despite the observed decrease in the density of benthic macroinvertebrates, their abundance was comparable to that observed in Polish lakes (Klimaszyk and Heymann 2010). Chironomids (Chironomidae) found at the site exposed to glyphosate were represented by individuals smaller in length while A. aquaticus only by adult, large individuals. The exact date of herbicide application remains unknown but it can be hypothesized that due to the high susceptibility of chironomids and A. aquaticus to glyphosate, the age structure of these organisms was affected resulting in elimination of younger A. aquaticus individuals as well as elimination of chironomids and recolonization of the habitat by a new generation after the glyphosate's influence had decreased. The high sensitivity of aquatic crustaceans to glyphosate formulas was demonstrated by Tsui and Lui (2004) in toxicity assays involving Hyalella azteca. Linz et al. (1999) demonstrated that although there was no significant difference between the number of Chironomidae in wetlands treated with glyphosate and the untreated, the number of the organisms at treated sites underwent a high degree of variation. The acute toxicity assay conducted by Buhl and Faerber (1989) found that a glyphosate-based formula

Table 1. Differences in the density (individuals per square metre) of benthic macroinvertebrate taxa found at the bathing area and control site in Lake Lednica

\begin{tabular}{|c|c|c|}
\hline & Bathing area & Control \\
\hline Oligochaeta * & 300 & 525 \\
\hline Hirudinea * & 100 & 400 \\
\hline $\begin{array}{l}\text { Tricladida } \\
\text { - Dendrocoelum sp. }\end{array}$ & - & 75 \\
\hline $\begin{array}{l}\text { Crustacea } \\
\text { Amphipoda * } \\
\text { - Gammarus pulex }\end{array}$ & 325 & 525 \\
\hline - Asellus aquaticus * & 450 & 1975 \\
\hline $\begin{array}{l}\text { Insecta } \\
\quad \text { - Trichoptera * }\end{array}$ & 450 & 600 \\
\hline - Megaloptera * & 875 & 975 \\
\hline - Ephemeroptera * & 275 & 475 \\
\hline $\begin{array}{l}\text { Diptera } \\
\text {-Chironomidae * } \\
\text { - Ceratopogonidae }\end{array}$ & $\begin{array}{c}2375 \\
50\end{array}$ & $\begin{array}{c}4025 \\
50\end{array}$ \\
\hline $\begin{array}{l}\text { Bivalvia } \\
\text { - Dreissena polymorpha * }\end{array}$ & 1325 & 2300 \\
\hline $\begin{array}{l}\text { Gastropoda } \\
\text {-Vivipariae * } \\
\text {-Lymnaeidae }\end{array}$ & $\begin{array}{l}50 \\
25\end{array}$ & $\begin{array}{c}200 \\
-\end{array}$ \\
\hline Total & 6575 & 12125 \\
\hline
\end{tabular}


(Rodeo ${ }^{\oplus}$, Monsanto Company, St. Louis, Missouri, USA) was practically non-toxic to Chironomus riparius. It can thus be concluded that the effect of this herbicide on midge larvae can be highly situation-dependent.

The abundance of several taxa at the glyphosate-treated site was, however, clearly lower; the effects of the herbicide were most likely short term due to the degradation process of the active ingredient. Studies conducted by Linz et al. (1999) revealed that invertebrate communities were not negatively affected in wetlands one and two years after the glyphosatebased herbicide was applied to control invasive cattail (Typha sp.). On the other hand, the chronic effect of glyphosate resulting, for example, from its regular use in agricultural catchment areas on aquatic macroinvertebrate communities and other organisms remains unknown and would require further studies. Interestingly, we have found that the area treated with glyphosate was characterized with a higher number of Gastropoda. This is consistent with the results obtained by Linz et al. (1999) and may result from mass decay of vegetation induced by the herbicide. It can thus be hypothesized that applications of glyphosate to aquatic vegetation in water bodies having already low levels of dissolved oxygen or high temperatures could become hazardous to living organisms because of increased eutrophication (Folmar et al. 1979; Linz and Homan 2011).

Apart from their main ingredient, glyphosatebased formulas contain surfactants added to increase the wetting of hydrophobic plant cuticles and increase penetration of the glyphosate into the plant tissues, which is further translocated within different organs (Solomon and Thompson 2003). We have found low concentrations of glyphosate in Phragmites australis collected from the treated site with the highest values observed for leaves - $24.7 \mu \mathrm{g} \mathrm{kg}^{-1}$ (Table 2). However as indicated in other studies, glyphosate is easily translocated within the plant after the herbicide is applied, and leaves are usually the main target organs (Solomon and Thompson 2003). Glyphosate content in P. australis tissues was at least 3 times lower than that found in parallel water samples. This may indicate the high rate of glyphosate degradation to AMPA in plants that underwent herbicide treatment. Thus their decomposition is unlikely to be able to serve as the secondary source of glyphosate for other aquatic organisms.

It has already been demonstrated that glyphosate can bioaccumulate in some organisms. For example, Contardo-Jara et al. (2009) found a high accu-
Table 2. Mean glyphosate content $\left(\mu \mathrm{gg}^{-1}\right)$ found in macroinvertebrates and Phragmites australis collected from Lake Lednica in April, $2011(\mathrm{n}=3)$

\begin{tabular}{lcl}
\hline \multicolumn{1}{c}{ Macroinvertebrates } & Bathing area & Control \\
\hline Chironomids & & \\
\hline Gastropoda & 10.2 & n.d. \\
\hline Other & 7.3 & n.d. \\
\hline \multicolumn{1}{c}{ Phragmites australis } & 8.1 & n.d. \\
\hline Leaves & 24.7 & n.d. \\
\hline Stems & 20.9 & n.d. \\
\hline Roots & 16.2 & n.d.
\end{tabular}

n.d. - not detected; Other: Ephemeroptera + Megaloptera + Trichoptera

mulation of this compound in Lumbriculus variegatus tissues. Moreover the same study also demonstrated that the formulation of glyphosate-based herbicide revealed higher permeability than the glyphosate itself with Bioaccumulation Factor (BAF) values reaching nearly 6.0 after 4 days of exposure to $50 \mu \mathrm{g} \mathrm{dm}^{-3}$. Other accumulation studies involved carp and tilapia and demonstrated even higher BAF values for glyphosate reaching up to 10 and 65.5 , respectively after 5 days of exposure (Wang et al. 1994). In both studies bioaccumulation of glyphosate was determined using labelled chemicals with BAF calculated from the concentration of radioactivity in biota and water. This method was impossible to implement in our study, thus we focused on determination of glyphosate in macroinvertebrate tissues. We found low glyphosate content in macroinvertebrates with the highest level determined for chironomids - $10.2 \mu \mathrm{g} \mathrm{kg}$. At the same time no glyphosate was found in any sample collected from the control site. The highest level of glyphosate was found in tissues of chironomids while the lowest in gastropods (Table 2). It can be concluded that glyphosate does not bioaccumulate in macroinvertebrates as the highest determined concentration was 9-fold lower than that found in parallel water samples. It is possible that glyphosate, which is mainly deposited to sediments in aquatic environments, has low availability for macroinvertebrates inhabiting bottom zones. Our study indicates that glyphosate-based herbicides may have an adverse effect on aquatic organisms including macroinvertebrate communities, thus their use in natural surface waters as well as terrestrial ecosystems adjacent to aquatic environments should be subject to strict limitation and monitoring. 


\section{References}

Bonnet J.L., Bonnemoy F., Dusser M., Bohatier J., 2007, Assessment of the potential toxicity of herbicides and their degradation products to non target cells using two microorganisms, the bacteria Vibriof ischeri and the ciliate Tetrahymena pyriformis, Environ. Toxicol. 22(1): 78-91.

Buhl K.J., Faerber N.L., 1989, Acute toxicity of selected herbicides and surfactants to larvae of the midge Chironomus riparius, Arch. Environ. Contam. Toxicol. 18(4): 530-536.

Contardo-Jara V., Klingelmann E., Wiegand C., 2009, Bioaccumulation of glyphosate and its formulation Roundup Ultra in Lumbriculus variegatus and its effects on biotransformation and antioxidant enzymes, Environ. Pollut. 157(1): 57-63.

Coupe R.H., Kalkhoff S.J., Capel P.D., Gregoire C., 2012, Fate and transport of glyphosate and aminomethylphosphonic acid in surface waters of agricultural basins, Pest. Manag. Sci. 68(1): 16-30.

Edge C.B., Gahl M.K., Thompson D.G., Houlahan J.E., 2013, Laboratory and field exposure of two species of juvenile amphibians to a glyphosate-based herbicide and Batrachochytrium dendrobatidis, Sci. Total Environ. 444: 145-152.

Folmar L.C., Sanders H.L., Julin A.M., 1979, Toxicity of the herbicide glyphosate and several of its formulations to fish and aquatic invertebrates, Arch. Environ. Contam. Toxicol. 8(3): 269-278.

Giesy J.P., Dobson S., Solomon K.R., 2000, Ecotoxicological risk assessment for Roundup herbicide, Rev. Environ. Contam. Toxicol. 167: 35-120.

Glusczak L., Loro V.L., Pretto A., Moraes B.S., Raabe A., Duarte M.F., da Fonseca M.B., de Menezes C.C., Valladão D.M., 2011, Acute exposure to glyphosate herbicide affects oxidative parameters in piava (Leporinus obtusidens), Arch. Environ. Contam. Toxicol. 61(4): 624-630.

Goldsborough L.G., Beck A.E., 1989, Rapid dissipation of glyphosate in small forest ponds, Arch. Environ. Contam. Toxicol. 18(4): 537-544.

Jones D.K., Hammond J.I., Relyea R.A., 2010, Roundup and amphibians: the importance of concentration, application time, and stratification, Environ. Toxicol. Chem. 29(9): 2016-2025.

Klimaszyk P., Heymann D., 2010, Vertical distribution of benthic macroinvertebrates in a meromictic lake (Lake Czarne, Drawieński National Park), Oceanol. Hydrobiol. Stud. 39(7): 99-106.

Linz G.M., Bleier W.J., Overland J.D., Homan H.J., 1999, Response of invertebrates to glyphosate-induced habitat alterations in wetlands, Wetlands 19(1): 220-227.

Linz G.M., Homar H.J., 2011, Use of glyphosate for managing invasive cattail (Typha spp.) to disperse blackbird (Icteridae) roosts, Crop Protect. 30(2): 98-104.

Modesto K.A., Martinez C.B., 2010, Effects of Roundup Transorb on fish: hematology, antioxidant defenses and acetylcholinesterase activity, Chemosphere 81(6): 781-787.
Pérez G.P., Vera M.S., Miranda L., 2011, Effects of Herbicide Glyphosate and Glyphosate-Based Formulations on Aquatic Ecosystems, [in:] Kortekamp A. (ed.), Herbicides and Environment, InTech Europe, Rijeka: 343-368.

Peruzzo P.J., Porta A.A., Ronco A.E., 2008, Levels of glyphosate in surface waters, sediments and soils associated with direct sowing soybean cultivation in north pampasic region of Argentina, Environ. Pollut. 156(1): 61-66.

Pieniążek D., Bukowska B., Duda W., 2003, Glifosat - nietoksyczny pestycyd? (Glyphosate - A non-toxic pesticide?) Med. Pracy 54(6): 579-583 (in Polish, English summary).

Relyea R. A., 2005, The impact of insecticides and herbicides on the biodiversity and productivity of aquatic communities, Ecol. Appl. 15(2): 618-627.

Rueppel M.L., Brightwell B.B., Schaefer J., Marvel J.T., 1977, Metabolism and degradation of glyphosate in soil and water, J. Agric. Food Chem. 25(3): 517-528.

Sandrini J.Z., Rola R.C., Lopes F.M., Buffon H.F., Freitas M.M., Martins Cde M., da Rosa C.E., 2013, Effects of glyphosate on cholinesterase activity of the mussel Perna perna and the fish Danio rerio and Jenynsia multidentata: In vitro studies, Aquat. Toxicol. 130-131: 171-173.

Schmidt H., Boas P., 2006, Accompanying experiments on weed control on public footways using the roller wiper 'Rotofix', Nachrichtenbl. Deut. Pflanzenschutzd. 58(2): 46-49.

Solomon K.R., Thompson D.G., 2003, Ecological risk assessment for aquatic organisms from over-water uses of glyphosate, J. Toxicol. Environ. Health B Crit. Rev. 6(3): 289-324.

Steinrücken H.C., Amrhein N., 1980, The herbicide glyphosate is a potent inhibitor of 5-enolpyruvylshikimic acid3-phosphate synthase, Biochem. Biophys. Res. Comm. 94(4): 1207-1212.

Tsui M.T.K., Chu L.M., 2004, Comparative toxicity of glyphosate-based herbicides: aqueous and sediment porewater exposures, Arch. Environ. Contam. Toxicol. 46(3): 316-323.

[USEPA] U.S. Environmental Protection Agency, 1993, R.E.D. Facts: glyphosate, US EPA: Office of Pesticide Programs, Washington, p. 7.

[USEPA] U.S. Environmental Protection Agency, 1986, Guidance for the reregistration of pesticide products containing glyphosate as the active ingredient, US EPA: Office of Pesticide Programs, Washington, p. 207.

Vera-Candioti J., Soloneski S., Larramendy M.L., 2013, Evaluation of the genotoxic and cytotoxic effects of glyphosate-based herbicides in the ten spotted live-bearer fish Cnesterodon decemmaculatus (Jenyns, 1842), Ecotoxicol. Environ. Saf. 89: 166-173.

Wang Y.S., Jaw C.G., Chen Y.L., 1994, Accumulation of 2,4$\mathrm{D}$ and glyphosate in fish and water hyacinth, Water Air Soil Pollut. 74(3-4): 397-403.

[WHO] World Health Organization, 1994, Glyphosate. Environmental health criteria 159, WHO: IPCS, Geneva, p. 177. 